\title{
Research Article \\ Effect of Fly Ash on Mortar Mixes with Quarry Dust as Fine Aggregate
}

\author{
Baboo Rai, ${ }^{1}$ Sanjay Kumar, ${ }^{1}$ and Kumar Satish ${ }^{2}$ \\ ${ }^{1}$ Department of Civil Engineering, National Institute of Technology, Patna, India \\ ${ }^{2}$ Department of Civil Engineering, Birla Institute of Technology, Patna, India
}

Correspondence should be addressed to Baboo Rai; baboo.rai@gmail.com

Received 22 October 2013; Accepted 12 February 2014; Published 27 March 2014

Academic Editor: Sridhar Komarneni

Copyright (c) 2014 Baboo Rai et al. This is an open access article distributed under the Creative Commons Attribution License, which permits unrestricted use, distribution, and reproduction in any medium, provided the original work is properly cited.

\begin{abstract}
This paper presents the results of an experimental investigation carried out to evaluate the compressive strength and transverse strength of 1:3 mortar mixes in which natural sand was replaced with $20 \%, 50 \%$, and $100 \%$ quarry dust by weight which were further modified by partially replacing cement with four percentages $(15 \%, 20 \%, 25 \%$, and $30 \%)$ of low calcium fly ash. The compressive strength was determined at 3, 7,28, and 50 days of age while transverse strength was determined at 28 and 50 days age. Test results revealed that the combined use of quarry rock dust and fly ash exhibited excellent performance due to efficient microfilling ability and pozzolanic activity.
\end{abstract}

\section{Introduction}

Out of various cementing materials, fly ash is the most widely used material worldwide. Fly ash is the byproduct of the combustion of pulverized coal in thermal power plants. According to the American Concrete Institute (ACI) Committee 116R [1], fly ash is defined as "the finely divided residue that results from the combustion of ground or powdered coal and that is transported by flue gasses from the combustion zone to the particle removal system." Worldwide, the estimated annual production of coal ash in 1998 was more than 390 million tons. The main contributors for this amount were China and India. Only about 14 percent of this fly ash was utilized, while the rest was disposed in landfills [2]. By the year 2010, the amount of fly ash produced worldwide is estimated to be about 780 million tons annually [3]. Fly ash, if not utilized, may present environmental concerns, and its storage/disposal will be expensive. The majority of fly ash produced in India is low calcium fly ash. The use of fly ash as admixture in cement mortar/concrete not only extends technical advantages to the properties of cement mortar/concrete but also contributes to the environmental pollution control.
Further, Hundreds of stone crushing plants in our country generate several thousand tons of quarry dust every day. This quarry dust is considered to be solid waste material. If it is possible to use this in making mortar/concrete by replacement of river sand, then it will solve the problem of its disposal. Moreover, the utilization of quarry dust, which can be called as manufactured sand after removal of microfines below 150 micron size by sieving, has been accepted in the industrially advanced countries of the West as the river sand, which is one of the constituents used in preparation of cement mortar/concrete, has become highly expensive and scarce. Usage of quarry dust as partial replacement to river sand/natural sand further modified by partial replacement of pozzolanic materials like fly ash is receiving more attention these days as their use generally improves the properties of cement/concrete.

A large volume of literature is available in area of use of supplementary cementitious materials in mortar/concrete as partial replacement for cement. Many researchers indicated that low calcium fly ash (class F) improves the interfacial zone microstructure. Class F fly ash contains less than $20 \%$ of lime $(\mathrm{CaO})$ and is pozzolanic in nature. Fly ash from the bituminous and anthracite coals is referred to as ASTM class F fly ash 
TABLE 1: Physical properties of cement.

\begin{tabular}{lccc}
\hline Property & Units & Results obtained & Specified value as per IS: 8112-1989 \\
\hline Specific gravity & & 3.14 & 3.15 \\
Fineness $(90 \mu$ sieve) & $\%$ & 7.5 & - \\
Soundness (Le-Chatelier Test) & $\mathrm{mm}$ & 3 & 10 (maximum) \\
Normal consistency (\% of cement by weight) & $\%$ & 28 & 30 \\
Setting time & & & 30 (minimum) \\
$\quad$ (i) Initial & Minutes & 199 & 600 (maximum) \\
$\quad$ (ii) Final & & 290 & 33.00 \\
Compressive strength & $\mathrm{MPa}$ & 35.9 & 43.00 \\
$\quad$ (i) Seven days & & 52.7 & \\
$\quad$ (ii) 28 days & & & \\
\end{tabular}

or low calcium fly ash. It consists of mainly an aluminosilicate glass and has less than 10 percent of $\mathrm{CaO}$ [4]. Tikalsky et al. [5] concluded on the basis of their research study that concrete containing fly ash as a cement replacement ( 0 to $35 \%$ ) on an equal weight basis displayed improved long term compressive, flexural strength. The variation of strength with age was also discussed by Wischers and Kuhlmann, Dhir et al., Malhotra, and Berry et al. [6-9]. Ganesh Babu and Siva Nageswara Rao [10] evaluated the cementing efficiency of fly ash in concrete at the different ages of 7,28 , and 90 days and at percentage replacement levels ranging from 15 to $75 \%$. In general, it was observed that fly ash exhibits very little cementing efficiency at the early ages and acts rather like fine aggregate (filler), but at later ages the pozzolanic property becomes effective leading to a considerable strength improvement.

Numbers of significant results have been reported on the use of quarry dust as partial replacement for fine aggregate. Quarry dust, a byproduct from the crushing process during quarrying activities, is one of those materials that have recently gained attentions to be used as concreting aggregates, especially as fine aggregates. Quarry dust has been used for different activities in the construction industry, such as road construction and manufacture of building materials, such as lightweight aggregates, bricks, tiles, and autoclave blocks. Researches have been conducted in different parts of the world, to study the effects of incorporation of quarry dust into concrete. Galetakis and Raka [11] studied the influence of varying replacement proportion of sand with quarry dust $(20$, 30 , and $40 \%$ ) on the properties of concrete in both fresh and hardened state. Safiuddin et al. [12] investigated the influence of partial replacement of sand with quarry dust and cement with mineral admixtures on the compressive strength of concrete whereas Celik and Marar [13] investigated the influence of partial replacement of fine aggregate with crushed stone dust at varying percentages on the properties of fresh and hardened concrete. Ghrici et al., Chindaprasirt et al., Curcio and DeAngelis, and Misra [14-18] investigated the effect of shape and size of fine aggregate on the strength of cement sand mortars and the possibility of replacing sand by crushed stone dust. The water requirement and the compressive strength are found higher for crushed stone dust as compared to that for conservative sand samples for
TABLE 2: Physical properties of fly ash.

\begin{tabular}{lcc}
\hline Sl. number & Physical properties & Observed values \\
\hline 1 & Specific gravity & 2.51 \\
2 & Initial setting time & $45 \mathrm{Min}$ \\
3 & Final setting time & $280 \mathrm{Min}$ \\
4 & Consistency & $35 \%$ \\
\hline
\end{tabular}

same grading and mix proportions. de Larrard and Belloc [19] studied the influence of aggregate on the compressive strength of normal- and high-strength concrete while Goble and Cohen [20] observed the influence of aggregate surface area on mechanical properties of mortar. Baali et al. [21] studied the mechanical response of mortar made with natural and artificial fine aggregates.

In the present investigation low calcium fly ash, a supplementary cementitious material, is used to improve the mechanical characteristics, namely, compressive strength and transverse strength of mortar using quarry dust as fine aggregate.

\section{Experimental Program}

\subsection{Material Properties}

2.1.1. Cement. The cement used was Ordinary Portland Cement (43 grade). The various laboratory tests conforming to Indian standard specification, IS: 4031-1996 specification, were carried out and the physical properties are shown in Table 1.

2.1.2. Fly Ash. Low calcium fly ash samples taken from Kahalgaon Thermal Power Plant, NTPC were used in this study. Fly ash shown in Figure 1 was not processed and was used as received. The sample satisfied the requirements of IS: 3812 (Part I). The physical and chemical properties as supplied by the Kahalgaon Thermal Power Plant, NTPC are shown in Tables 2 and 3.

2.1.3. Quarry Dust. The quarry dust used in this study was used as a partial replacement for fine aggregate and 
TABLE 3: Chemical properties of fly ash.

\begin{tabular}{lccc}
\hline Sl. number & Test conducted & Observed values (\%) & Requirement as per IS: 1320-1981 \\
\hline 1 & Loss of ignition & 2.32 & $5.0(\mathrm{max})$ \\
2 & Silica as $\mathrm{SiO}_{2}$ & 42.04 & $\mathrm{SiO}_{2}+\mathrm{Fe}_{2} \mathrm{O}_{3}+\mathrm{Al}_{2} \mathrm{O}_{3}=70$ \\
3 & Iron as $\mathrm{Fe}_{2} \mathrm{O}_{3}$ & 4.40 & - \\
4 & $\mathrm{Alumina}$ as $\mathrm{Al}_{2} \mathrm{O}_{3}$ & 33.60 & - \\
5 & Calcium as $\mathrm{CaO}$ & 12.73 & - \\
6 & Magnesium as $\mathrm{MgO}$ & 0.00 & $5.0(\max )$ \\
7 & Sulphate as $\mathrm{SO}_{3}$ & 0.40 & $3.0(\max )$ \\
8 & Lime reactivity & $4 \mathrm{~N} / \mathrm{mm}^{2}$ & $4.5(\max )$ \\
\hline
\end{tabular}

TABLE 4: Physical properties of quarry dust and natural sand.

\begin{tabular}{lccc}
\hline Property & Quarry dust & Natural sand & Test method \\
\hline Specific gravity & 2.54 & 2.67 & IS 2386 (Part III) 1963 \\
Bulk relative density $\left(\mathrm{kg} / \mathrm{m}^{3}\right)$ & 1800 & 1770 & IS 2386 (Part III) 1963 \\
Absorption (\%) & 1.4 & 1.2 & IS 2386 (Part III) 1963 \\
Moisture content (\%) & Nil & Nil & IS 2386 (Part III) 1963 \\
\hline
\end{tabular}

TABLE 5: Sieve analysis of quarry dust.

\begin{tabular}{lcccc}
\hline $\begin{array}{l}\text { IS sieve } \\
\text { designation }\end{array}$ & $\begin{array}{c}\text { Weight } \\
\text { retained }(\mathrm{kg})\end{array}$ & $\begin{array}{c}\text { Percentage of } \\
\text { weight retained }\end{array}$ & $\begin{array}{c}\text { Cumulative } \\
\text { percentage of } \\
\text { weight retained }\end{array}$ & Percentage of fineness by weight \\
\hline $4.75 \mathrm{~mm}$ & 0.40 & 0.040 & 4.00 & 96 \\
$2.36 \mathrm{~mm}$ & 0.025 & 0.065 & 6.50 & 93.50 \\
$1.18 \mathrm{~mm}$ & 0.117 & 0.182 & 18.20 & 81.80 \\
$600 \mathrm{micron}$ & 0.152 & 0.334 & 33.40 & 66.60 \\
300 micron & 0.443 & 0.777 & 77.70 & 22.30 \\
150 micron & 0.170 & 0.947 & 94.70 & 5.30 \\
\hline
\end{tabular}

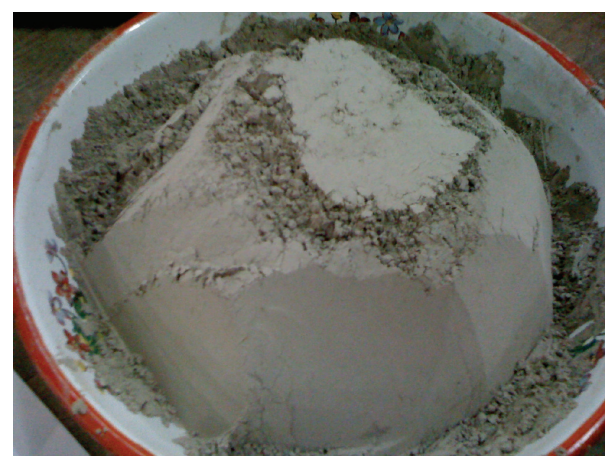

FIGURE 1: Fly ash sample.

was obtained locally. The sample of quarry dust, shown in Figure 2, was analyzed in terms of physical properties and is presented in Table 4. The sieve analysis results are presented in Table 5.

2.1.4. Sand. Ordinary sand from river Sone having fineness modulus of 2.60 was used. Sand after sieve analysis (Table 6) conforms to zone II as per IS: 383-1970.

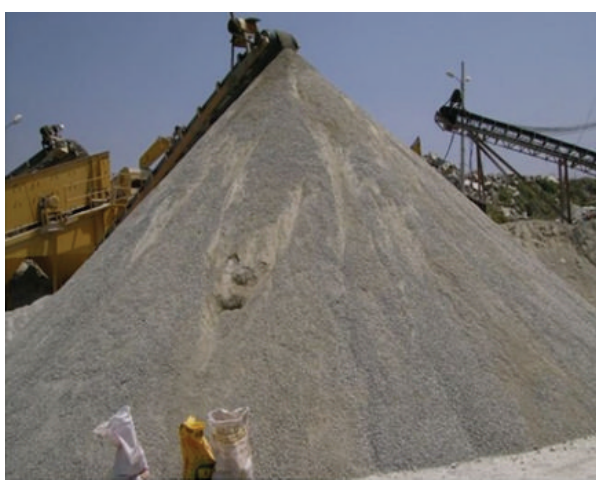

FIGURE 2: Quarry dust sample.
2.2. Mortar Mixes. Two control mixes, namely, 1:3 cement sand mortar mix, QC series, with 0, 20, 50, and 100 percent partial replacement by weight of natural sand with quarry dust and 1:3 cement sand mortar mix with 20\% partial replacement by weight of natural sand with quarry dust which was further modified by replacing $0 \%, 15 \%, 20 \%, 25 \%$, and $30 \%$ cement with low calcium fly ash by weight (QF series) 
TABLE 6: Sieve analysis of fine aggregate.

\begin{tabular}{|c|c|c|c|c|c|}
\hline IS sieve $(\mathrm{mm})$ & Weight retained $(\mathrm{Kg})$ & Cumulative weight $(\mathrm{Kg})$ & Percentage retained & Percentage passing & Remarks \\
\hline 4.75 & 0.034 & 0.034 & 3.4 & 96.6 & \multirow{6}{*}{$\begin{array}{l}\text { Sand zone II as per } \\
\text { IS: } 383-1970 \\
\text { CLAUSE } 4.3 \text { Table } 4\end{array}$} \\
\hline 2.36 & 0.026 & 0.060 & 6 & 94 & \\
\hline 1.18 & 0.140 & 0.200 & 20 & 80 & \\
\hline 600 & 0.162 & 0.362 & 36.2 & 63.30 & \\
\hline 300 & 0.425 & 0.787 & 78.7 & 21.30 & \\
\hline 150 & 0.185 & 0.972 & 97.2 & 2.30 & \\
\hline
\end{tabular}

TABle 7: Mix proportioning for 1:3 mortar mixes.

\begin{tabular}{lccccccc}
\hline Sample name & $\begin{array}{c}\text { Cement } \\
(\mathrm{gm})\end{array}$ & $\begin{array}{c}\text { Fly ash } \\
\text { (\% of cement) }\end{array}$ & $\begin{array}{c}\text { Natural sand } \\
(\mathrm{gm})\end{array}$ & $\begin{array}{c}\text { Quarry dust } \\
\text { (\% of sand) }\end{array}$ & $\begin{array}{c}\text { Water } \\
\text { w/c } \\
\text { (for cement) } \\
\text { (gm) }\end{array}$ & $\begin{array}{c}\text { Water for fly } \\
\text { ash (gms) }\end{array}$ \\
wC1 & 1200 & 0 & 3600 & 0 & 0.44 & 528 & 0 \\
QC2 & 1200 & 0 & 2880 & 20 & 0.44 & 528 & 0.44 \\
QC3 & 1200 & 0 & 1800 & 50 & 0.44 & 528 & 0.44 \\
QC4 & 1200 & 0 & 0 & 100 & 0.44 & 528 & 0.44 \\
QF1 & 1020 & 15 & 2880 & 20 & 0.44 & 449 & 0.44 \\
QF2 & 960 & 20 & 2880 & 20 & 0.44 & 422 & 32 \\
QF3 & 900 & 25 & 2880 & 20 & 0.44 & 396 & 0.39 \\
QF4 & 840 & 30 & 2880 & 20 & 0.44 & 370 & 40 \\
\hline
\end{tabular}

TABLE 8: Compressive strength test result for QC series.

\begin{tabular}{lcccc}
\hline Sample name & Three-day strength $\left(\mathrm{N} / \mathrm{mm}^{2}\right)$ & Seven-day strength $\left(\mathrm{N} / \mathrm{mm}^{2}\right)$ & 28-day strength $\left(\mathrm{N} / \mathrm{mm}^{2}\right)$ & 50 -day strength $\left(\mathrm{N} / \mathrm{mm}^{2}\right)$ \\
\hline QC1 & 23.84 & 31.84 & 41.15 & 42.44 \\
QC2 & 24.68 & 33.62 & 43.70 & 44.88 \\
QC3 & 24.48 & 33.48 & 42.85 & 44.15 \\
QC4 & 24.26 & 31.88 & 35.86 & 40.56 \\
\hline
\end{tabular}

were prepared. Properties of mortar, namely, compressive strength and transverse strength, have been selected for study.

According to the guidelines for the fly ash modified mortar mixes, the cementing coefficient of 0.30 has been considered for fly ash as the lubricating action of fly ash reduces water requirement and hence drying shrinkage. The water to cement $(w / c)$ ratio for all the mixes was fixed at 0.44 and water to powder $(w / p)$ ratio was calculated as

$$
\begin{aligned}
W_{P}= & W_{C}+W_{F}=\left(\frac{w}{c}\right) \\
& \times \text { weight of cement }+0.3 \times\left(\frac{w}{c}\right) \\
& \times \text { weight of fly ash. }
\end{aligned}
$$

Here $W_{P}$ represents weight of water required for powder consisting of cement and fly ash. The mortar mix proportion is given in Table 7 .

2.3. Test Method. Compressive strength of cement mortar was determined on cubes of face $50 \mathrm{~cm}^{2}$ in area $(7.06 \mathrm{~cm}$ cubes) made with one part of cement and three parts of standard sand (confirming to IS: 4031-1996) by weight and water corresponding to $25 \%$ of normal consistency plus $3 \%$ of the combined weight of the cement or sand. The mortar was placed in the standard $7.06 \mathrm{~cm}$ size moulds and compacted with ramming. The specimens were taken out of curing tank at designated ages $(3,7,28$, and 50 days) and tested for their compressive strength.

The cement mortar specimens of size $40 * 40 * 160 \mathrm{~mm}$ were prepared for transverse strength test. Four $\mathrm{kN}$ flexure testing machine (electrically operated) was used to determine the transverse strength of mortars. The test equipment meets the essential requirements of IS: 1727-1967. The transverse strength $(T)$ of the specimen is calculated as per IS: 4031, Part 8

$$
T=0.234 \times P
$$

where $P$ is applied load in $\mathrm{KN}$ at the time of breaking and $T$ is in $\mathrm{kgf} / \mathrm{cm}^{2}$.

\section{Results and Discussion}

3.1. Compressive Strength Test Results. The results of compressive strength test are shown in Tables 8 and 9. Figures 3 and 4 show the variation of compressive strength of all the mixes 
TABLE 9: Compressive strength test result for QF series.

\begin{tabular}{lcccc}
\hline Sample name & Three-day strength $\left(\mathrm{N} / \mathrm{mm}^{2}\right)$ & Seven-day strength $\left(\mathrm{N} / \mathrm{mm}^{2}\right)$ & 28-day strength $\left(\mathrm{N} / \mathrm{mm}^{2}\right)$ & 50 -day strength $\left(\mathrm{N} / \mathrm{mm}^{2}\right)$ \\
\hline QF1 & 24.84 & 32.84 & 43.00 & 52.62 \\
QF2 & 24.88 & 33.62 & 42.45 & 53.55 \\
QF3 & 24.48 & 33.84 & 42.70 & 54.38 \\
QF4 & 24.26 & 31.88 & 43.84 & 55.65 \\
\hline
\end{tabular}

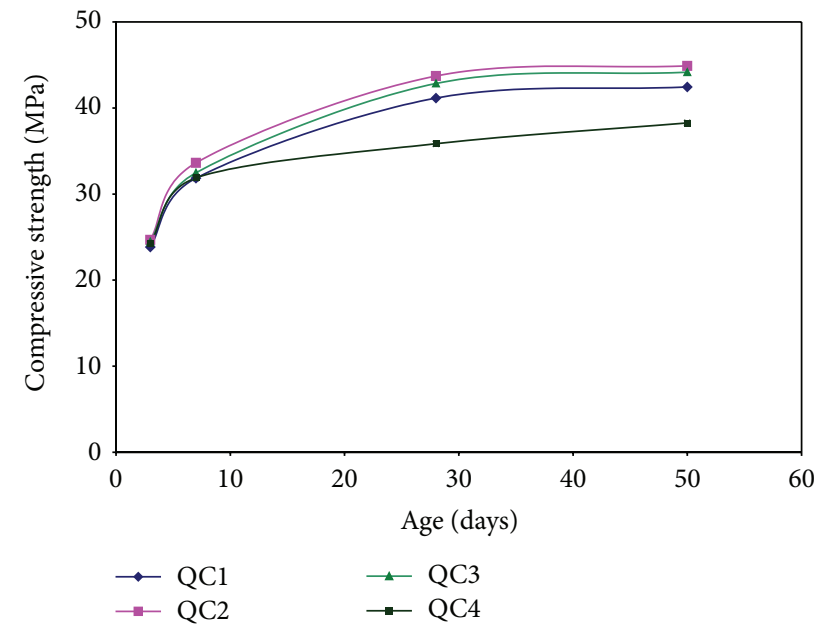

Figure 3: Compressive strength test results for QC series.

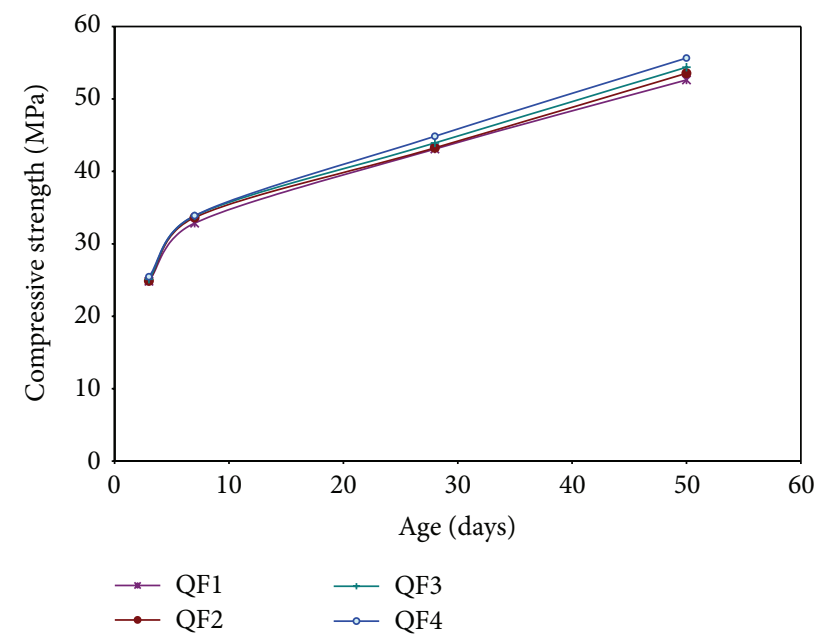

FIGURE 4: Compressive strength test results for QF series.

at different ages. Examining the strength at 3 days and 7 days of age it can be seen that increasing the quarry dust content from $0 \%$ to $100 \%$ has caused minimal increase in compressive strength for fly ash content of $0 \%$. However, examining the strength at 28 days and 50 days of age it can be seen that the rate of increase in compressive strength decreases when natural sand was replaced by $50 \%$ and $100 \%$ quarry dust. This decrease is significant when natural sand is completely replaced by quarry dust. The decrease in compressive strength is almost $13 \%$ and $10 \%$ as compared with the strength of reference mix (QC1) at 28 and 50 days. Mix proportion

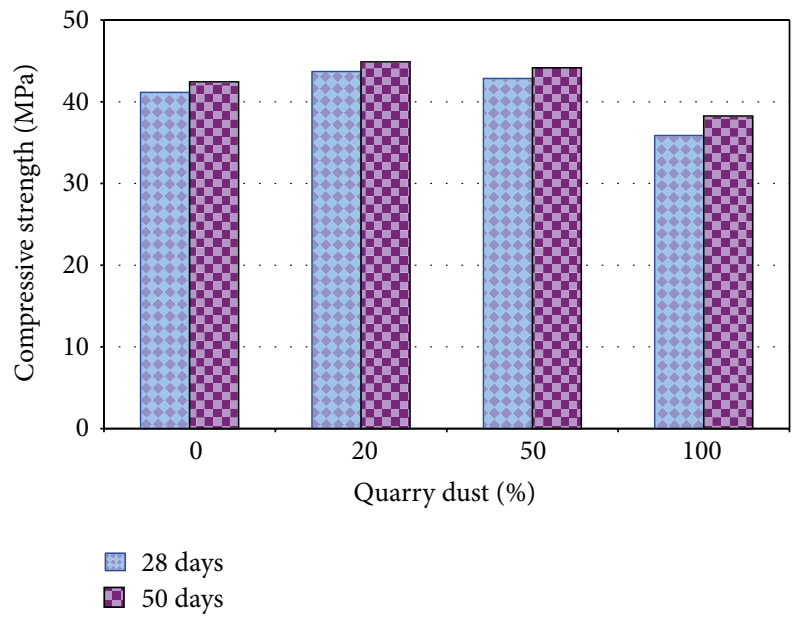

FIGURE 5: Variation of compressive strength with various percentage of quarry dust replacement in natural sand.

QC2 revealed an increase of compressive strength up to $6 \%$ at both 28 days and 50 days as compared to reference mix while the increase was $4 \%$ in case of mix proportion QC3 when compared to reference mix QC1. This may be due to the fact that $20 \%$ replacement of natural sand by quarry dust may show the optimum reaction with optimum filler capacity. It can be concluded that $20 \%$ replacement of natural sand by quarry dust will yield the maximum strengths for cement mortar. Figure 5 represents the variation of compressive strength at 28 and 50 days for mortar mixes of QC series with different percentages of quarry dust.

Further when fly ash is partially replaced with cement from 0 to $30 \%$ in mortar with $20 \%$ quarry dust (QF series), there is an overall increase in strength at 3 days, 7 days, and 28 days of age. The drop in compressive strength due to conversion reaction decreases with increase in fly ash content for a given water to powder ratio. The increase in fly ash content improves the compressive strength, for a given water to powder ratio. It was observed that the decrease in early strength by the addition of fly ash is ameliorated by the addition of quarry dust. Examining the data obtained at 50 days it can be seen that in general there is a considerable increase in strength and the increase is almost 32\% for mortar mix QF4 with 20\% quarry dust and 30\% fly ash as compared with reference mix (QC1). The variation of compressive strength at 28 and 50 days for mortar mixes of QF series with various percentages of fly ash in cement can be observed from Figure 6 while Figure 7 represents the percentage increase or 


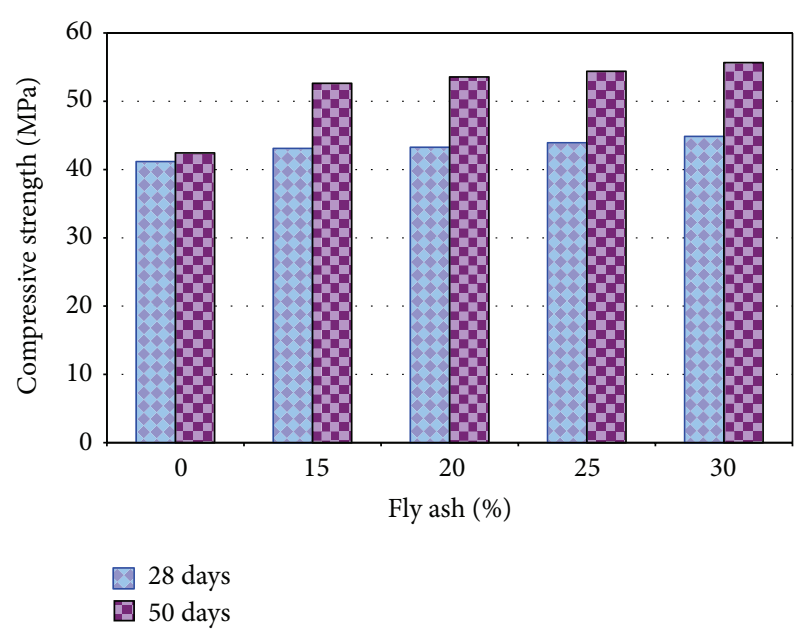

FIGURE 6: Variation of compressive strength with various percentage of fly ach replacement in cement.

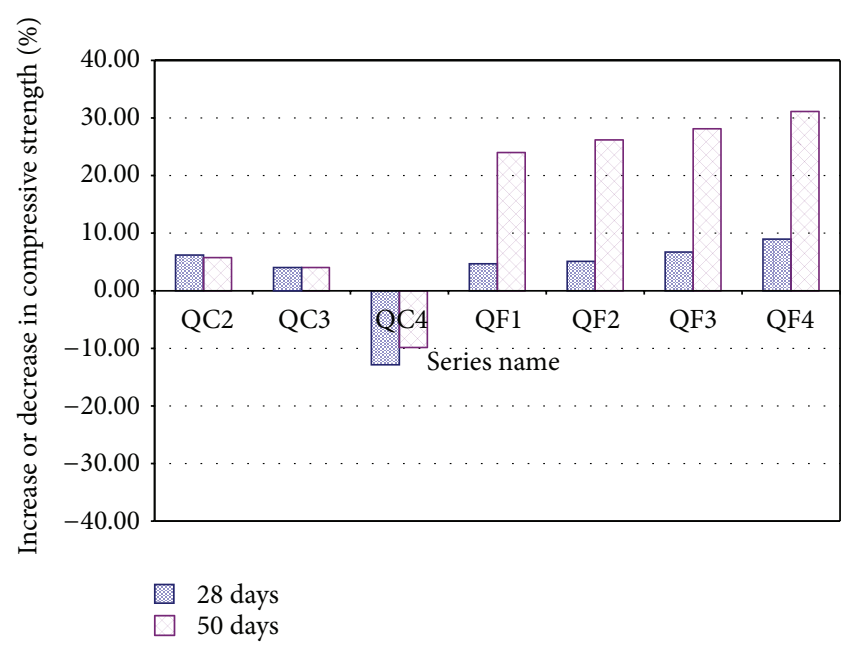

FIGURE 7: Compressive strength test results.

TABLE 10: Transverse strength test result.

\begin{tabular}{lcc}
\hline Mix proportion & 28 days $\left(\mathrm{N} / \mathrm{mm}^{2}\right)$ & 50 days $\left(\mathrm{N} / \mathrm{mm}^{2}\right)$ \\
\hline QC1 & 2.06 & 2.15 \\
QC2 & 1.95 & 2.25 \\
QC3 & 1.88 & 2.12 \\
QC4 & 1.86 & 2.20 \\
QF1 & 2.00 & 2.57 \\
QF2 & 2.08 & 2.72 \\
QF3 & 2.10 & 2.85 \\
QF4 & 2.12 & 3.07 \\
\hline
\end{tabular}

decrease of compressive strength for all the mortar mixes at 28 and 50 days of age.

3.2. Transverse Strength Test. The results of the transverse strength tests for all the mortar mixes are shown in Table 10 and illustrated in Figure 8. These results show that the

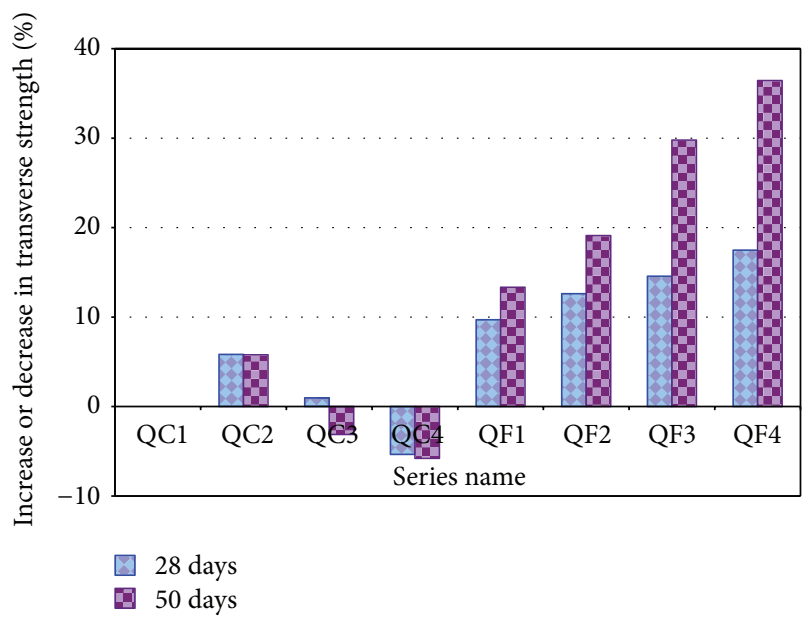

Figure 8: Transverse strength test results.

transverse strength of fly ash modified mortar mixes increases with the increase of the fly ash ratio. It can be seen that there is significant increase in transverse strength when compared with that of the reference mix. The increase is almost $18 \%$ and $36 \%$ at 28 and 50 days of age. This trend can again be attributed to the fact that fly ash possesses large pozzolanic reaction and improved interfacial bond between paste and aggregates.

\section{Conclusions}

From the present investigation and limited observations reported, the combined use of quarry rock dust and fly ash exhibited excellent performance due to efficient microfilling ability and pozzolanic activity. It was observed that the decrease in early strength by the addition of fly ash is ameliorated by the addition of quarry dust. Therefore, the results of this study provide a strong recommendation for the combined use of quarry rock dust and fly ash in mortar/concrete manufacturing. Quarry dust qualifies itself as suitable substitute for river sand. Thus, it can be concluded that the replacement of natural sand with quarry dust, as partial replacement, in mortar/concrete is possible. However, it is advisable to carry out trial casting with quarry sand proposed to be used, in order to arrive at the water content and mix proportion to suit the required workability levels and strength requirement. Also it is advisable to remove excess fines of size up to 150 microns by washing.

\section{Conflict of Interests}

The authors declare that there is no conflict of interests regarding the publication of this paper.

\section{References}

[1] "Use of fly ash in concrete," ACI Committee 232, American Concrete Institute, Farmington Hills, Mich, USA, 2004. 
[2] V. M. Malhotra and A. A. Ramezanianpour, Fly Ash in Concrete, CANMET, Ottawa, Canada, 1994.

[3] V. M. Malhotra, "Making concrete, "Greener" with fly ash," ACI Concrete International, vol. 21, no. 5, pp. 61-66, 1999.

[4] V. M. Malhotra, "Introduction: sustainable development and concrete technology," ACI Concrete International, vol. 24, no. 7, p. 22, 2002.

[5] P. J. Tikalsky, P. M. Carrasquillo, and R. L. Carrasquillo, "Strength and durability considerations affecting mix proportioning of concrete containing fly ash," ACI Materials Journal, vol. 85, no. 6, pp. 505-511, 1988.

[6] G. Wischers and K. Kuhlmann, "Eco-balance of cement and concrete," BFT, no. 11, pp. 33-40, 1991.

[7] R. K. Dhir, N. A. Henderson, and Limbachiya, Use of Recycled Concrete Aggregate, Thomas Telford, London, UK, 1998.

[8] V. M. Malhotra, "Role of supplementary cementing materials in reducing greenhouse gas emissions," in Infrastructure Regeneration and Rehabilitation Improving the Quality of Life Through Better Construction: A Vision for the Next Millennium, pp. 2742, Sheffield Academic Press, Sheffield, UK, 1999.

[9] E. E. Berry, R. R. Hemminge, W. S. Longlay, and C. G. Carette, "Beneficiated fly ash hydration, microstructure and strength development in portland system," in Proceedings of the $3 \mathrm{rd}$ International Congress Fly Ash, Silica Fume, Slag and National Pozzolana in Concrete, V. M. Malhotra, Ed., vol. 114, ACI SP 11411, pp. 241-273, Trondeheim, Norway, 1989.

[10] K. Ganesh Babu and G. Siva Nageswara Rao, "Efficiency of fly ash in concrete with age," Cement and Concrete Research, vol. 26, no. 3, pp. 465-474, 1996.

[11] M. Galetakis and S. Raka, "Utilization of limestone dust for artificial stone production: an experimental approach," Minerals Engineering, vol. 17, no. 2, pp. 355-357, 2004.

[12] M. Safiuddin, M. F. M. Zain, M. F. Mahmud, and R. S. Naidu, "Effect of quarry dust and mineral admixtures on the strength and elasticity of concrete," in Proceedings of the Conference on Construction Technology, pp. 68-80, Kota Kinabalu, Malaysia, 2001.

[13] T. Celik and K. Marar, "Effects of crushed stone dust on some properties of concrete," Cement and Concrete Research, vol. 26, no. 7, pp. 1121-1130, 1996.

[14] M. Ghrici, S. Kenai, and M. Said-Mansour, "Mechanical properties and durability of mortar and concrete containing natural pozzolana and limestone blended cements," Cement and Concrete Composites, vol. 29, no. 7, pp. 542-549, 2007.

[15] P. Chindaprasirt, N. Buapa, and H. T. Cao, "Mixed cement containing fly ash for masonry and plastering work," Construction and Building Materials, vol. 19, no. 8, pp. 612-618, 2005.

[16] P. Chindaprasirt, C. Jaturapitakkul, and T. Sinsiri, "Effect of fly ash fineness on compressive strength and pore size of blended cement paste," Cement and Concrete Composites, vol. 27, no. 4, pp. 425-428, 2005.

[17] F. Curcio and B. A. DeAngelis, "Dilatant behavior of superplasticized cement pastes containing metakaolin," Cement and Concrete Research, vol. 28, no. 5, pp. 629-634, 1998.

[18] V. N. Misra, "Use of stone dust from crushers in cement sand mortar," Indian Concrete Journal, vol. 58, no. 8, pp. 219-223, 1984.

[19] F. de Larrard and A. Belloc, "The influence of aggregate on the compressive strength of normal and high-strength concrete," ACI Materials Journal, vol. 94, no. 5, pp. 417-426, 1997.
[20] C. F. Goble and M. D. Cohen, "Influence of aggregate surface area on mechanical properties of mortar," ACI Materials Journal, vol. 96, no. 6, pp. 657-662, 1999.

[21] L. Baali, A. Naceri, and R. Mehamed, "Mechanical response of mortar made with natural and artificial fine aggregates," Asian Journal of Civil Engineering (Building and Housing), vol. 9, pp. 85-92, 2007. 

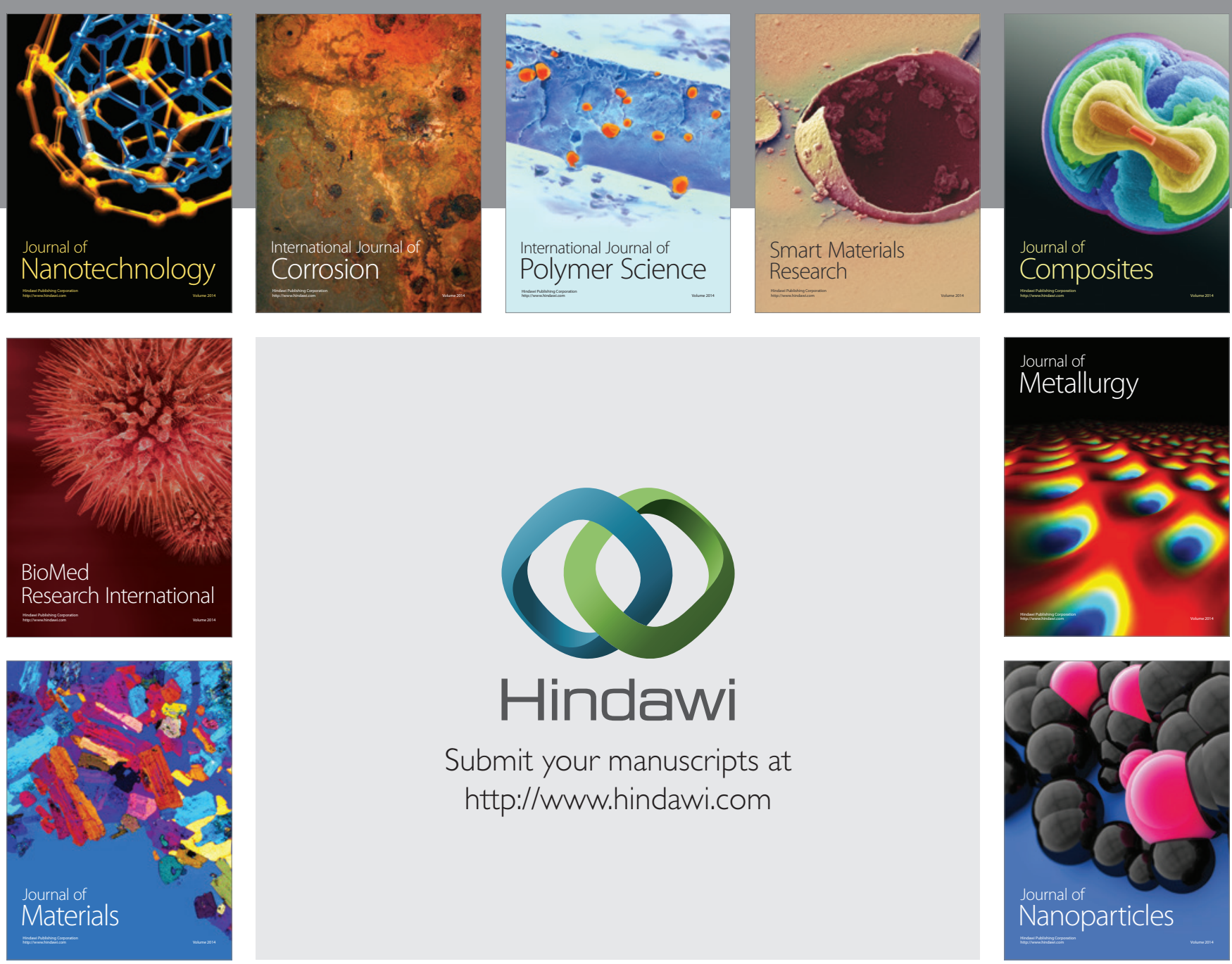

Submit your manuscripts at http://www.hindawi.com
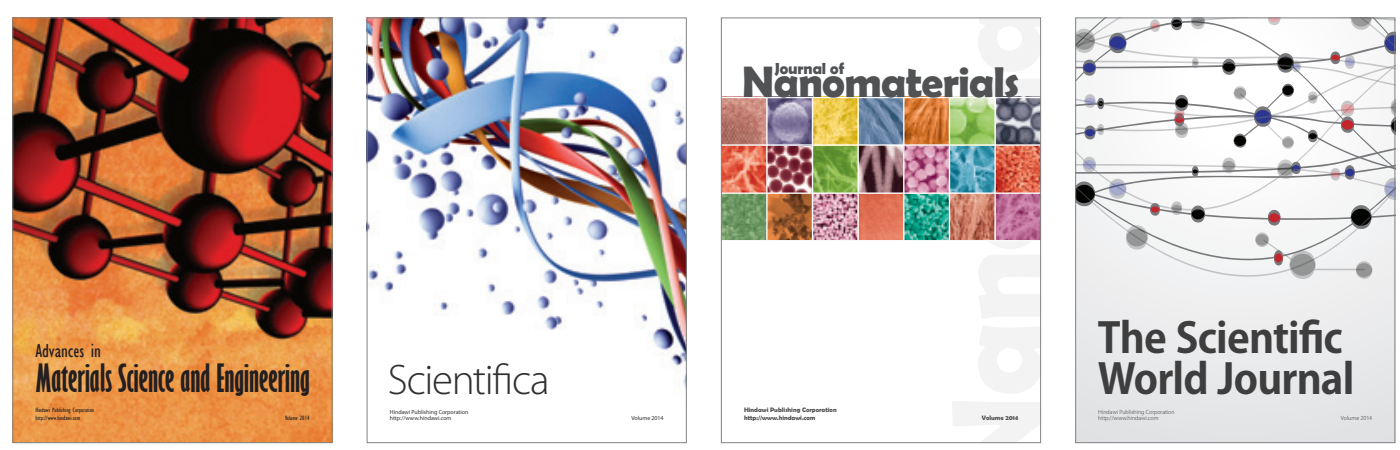

\section{The Scientific World Journal}
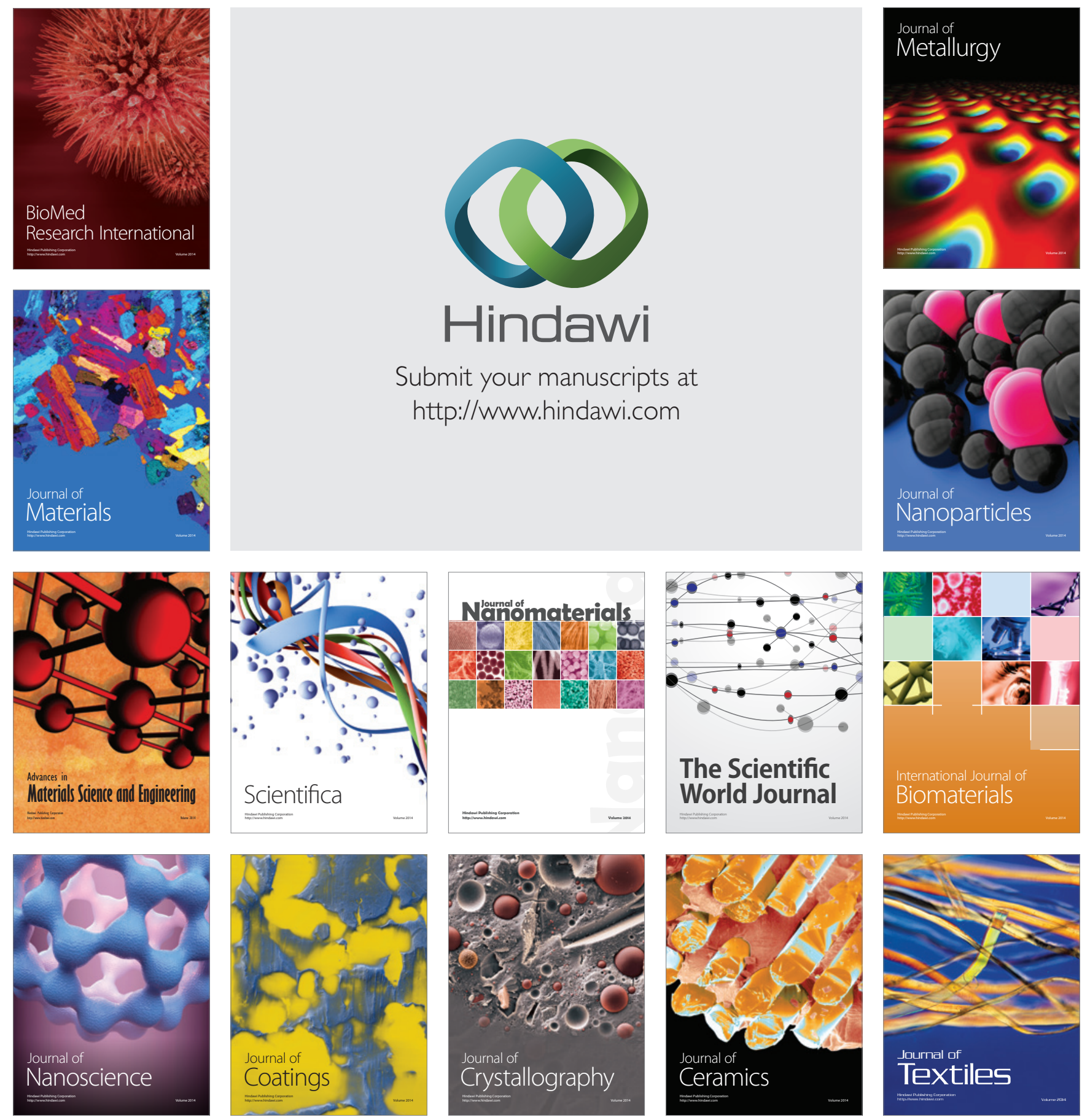